\title{
Effect of wind speed on the level of particulate matter PM10 concentration in atmospheric air during winter season in vicinity of large combustion plant
}

\author{
Robert Cichowicz ${ }^{1}$ (D) $\cdot$ Grzegorz Wielgosiński $^{2} \cdot$ Wojciech Fetter ${ }^{3}$
}

Received: 17 January 2019 / Accepted: 21 April 2020 /

Published online: 17 May 2020

(C) The Author(s) 2020

\begin{abstract}
The concentrations of suspended particulate matter PM10 in two-month winter period, i.e. December-January in years 2009-2015, were analyzed in relation to the values of wind speed in that time. It was possible to analyze results of air pollution measurements performed in the measuring station from the perspective of their higher levels in winter seasons (so-called smog episodes). Results from 3 stations of the Regional Inspectorate for Environmental Protection in Poznań (WIOŚ Poznań) served for better presentation of smog episodes in the region (black smog) and aimed at verification of correctness of the measurements of pollution immission in the monitoring station in Piotrkowice which is situated in vicinity of large combustion plant. The analysis confirmed that with low speeds of wind higher values of particulate matter PM10 were observed. The results of the analysis also show the displacement of pollutants according to the current wind direction or their local persistence for a longer time over one area.
\end{abstract}

Keywords Air quality $\cdot$ Smog episodes $\cdot$ Particulate matter PM10 $\cdot$ Wind speed

\section{Introduction}

Air quality and pollution levels are a problem not only in industrial and highly urbanized areas but also in typical agricultural areas. This is due to the spread of pollution (without any restrictions) according to the direction of wind affecting the area. For this reason it is important

Robert Cichowicz

ROBERT.CICHOWICZ@P.LODZ.PL

1 Faculty of Architecture, Civil and Environmental Engineering, Lodz University of Technology, Al. Politechniki 6, 90-924 Lodz, Poland

2 Faculty of Process and Environmental Engineering, Lodz University of Technology, Wolczanska 175, 90-924 Lodz, Poland

3 Department of Environmental Protection of Pątnów-Adamów-Konin Power Complex S. A, Kazimierska 45, 62-510 Konin, Poland 
to analyze both the size and extent of the pollution. Without the determination of these quantities it is not possible to carry out appropriate measures that may be aimed at improving the state of environment (Cichowicz and Wielgosiński 2015a, 2015b; Deligiorgi et al. 2013; EEA Report No 28 2016; Moreira and Vilhena 2009; Turner 1994).

Among atmospheric pollutants, unfortunately, there are also particles of both PM10 and PM2.5 whose presence may have a negative impact on human health. It is known that even brief exposure to very fine particles of suspended particulate matter can lead to some adverse changes in the human body (Samet et al. 2009; Brook et al. 2014; Huang et al. 2012). Particularly high amounts of particulate matter are emitted from the chemical, mining, metallurgical and construction industries (cement production) and, above all, as a result of the activity of power plants. For this reason both the concentration of particulate matter and its precipitation are important indicators of atmospheric pollution. However, not only its concentration determines its harmfulness, but also chemical and mineralogical composition (Seaton et al. 1995; Kampa and Castanas 2008).

Suspended particulate matter is also responsible for the so-called smog, which is a combination of mist and atmospheric pollutants, and is produced in an unnatural way and occurs primarily over large industrialized urban agglomerations. As an essential component of smog, suspended particulate matter is mostly found in London acid smog and slightly in photochemical smog (Los Angeles type) (Makhiniashvili and Makles 2006). In Poland, smog episodes will appear for a few years every winter. In fact this is a slightly different kind of smog from the one described in the literature of acidic smog called London type. The winter smog occurring in Poland is closely related to the socalled low emission coming from individual heating systems in the city centers and it consists of dust in from PM10 and polyaromatic hydrocarbons, especially benzo(a)pyrene. Additionally, in the winter season in Poland, especially in Polish towns, smog episodes i.e. extremely high mass concentrations of particulate matter PM10 and PM2.5 are observed in high-altitude weather, with negative temperatures, low wind and temperature inversion, at the inflow of cold air from the east. These are completely different atmospheric conditions from the conditions occurring during the so-called London-type smog.

\section{Experimental}

The analysis covered data from the two-month winter period, i.e. December-January in years 2009-2015, for PM10 particulate matter that came from an automatic atmospheric air monitoring station located in Poland in eastern Wielkopolska in Konin Region in the municipality of Ślesin, in Piotrkowice located near large combustion plants. PM10 concentrations were also compared with wind speed values and data from 3 stations of the Voivodship Inspectorate for Environmental Protection (Poznań-Botanik station, Poznań-Polanka station and KoninWyszyński station), two located in the large city (Poznań, about $100 \mathrm{~km}$ from Piotrkowice station) and one in a nearby city (Konin).

The largest plants affecting the quality of atmospheric air of the Konin Region are power plants forming the Pątnów-Adamów-Konin Complex Power Plant S.A. (ZE PAK S.A.) (Fig. 1) the aluminum smelter (Impexmetal S.A. Aluminum Konin) and municipal solid waste incinerator (Municipal Waste-to-Energy Plant). The Piotrkowice station lies on the dominant 
wind direction compared to the Patnów power plant (part of ZE PAK). In addition, the level of particulate matter is also affected by the agricultural sector (the area surrounding the arable land accounts for almost $55 \%$ of the total area of the district) and the municipal sector (Zarzycki et al. 2007).

PM10 particulate measurement was carried out using a TEOM 1400a analyzer produced by Rupprecht \& Patashnick Co, currently Thermo Scientific (with a concentration range of $5 \mu \mathrm{g} / \mathrm{m}^{3}$ to several $\mathrm{mg} / \mathrm{m}^{3}$ ) placed in a container. The analyzer consists of a control element, measuring head and air intake (the tested air is taken from the outside by an air intake which, thanks to its design, ensures the intake of particulate matter with a size smaller than $10 \mu \mathrm{m}$. Next, the air sample is heated in the measuring head to $50{ }^{\circ} \mathrm{C}$ and then directed to the measuring filter at a flow rate of $31 / \mathrm{min}$. The filter, on which particulate matter is collected, is placed on the head, which is a thin glass tube subjected to vibrations at a specified frequency. The change in vibration frequency of the head and the filter is proportional to the mass increase of the particulate matter deposited on the filter. The more particulate matter appears on the measuring filter per time unit, the lower the vibration frequency of the head and the higher the particulate matter concentration recorded by the analyzer. The control unit regulates the vibration frequency of the head and filter, air sample flow, its temperature and degree of filling the filter). Sensors mounted in meteorological radiation shields with accuracy of $\pm 0.2{ }^{\circ} \mathrm{C}$ and $\pm 1 \% \mathrm{RH}$ (at $+20.0^{\circ} \mathrm{C}$ ) were used to measure air temperature and humidity (Vaisala HMP 45A sensor, Pt1000 sensor and HUMICAP 180 sensor). Additionally, to measure the direction and

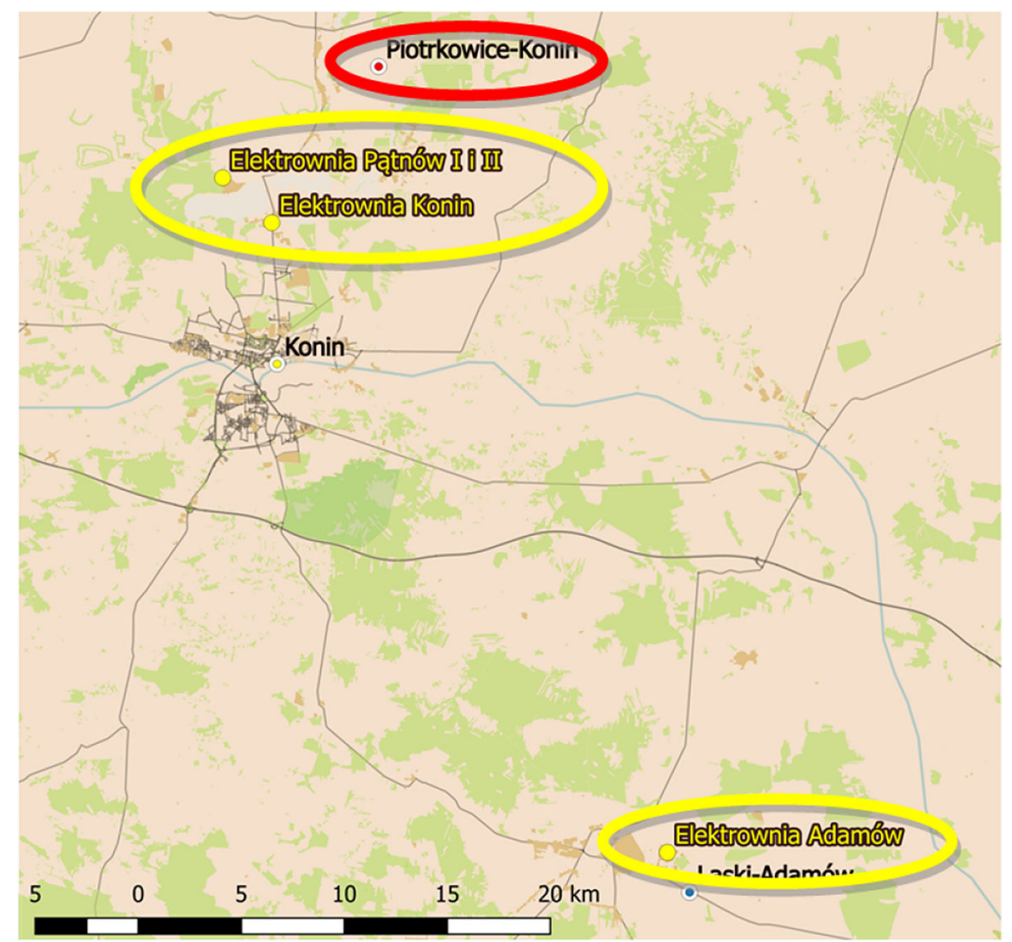

Fig. 1 Location of power plants forming the Pątnów-Adamów-Konin Complex Power Plant S.A. (QGIS version 2.18.19) 
velocity of wind, an anemometric sensor was installed at the top of the $12 \mathrm{~m}$ meteorological mast which had no moving parts and was resistant to adverse weather conditions. In summary, the measuring stations were equipped with analyzers for continuous pollution measurements, and the PM10 measurements were based on a method equivalent to the reference method and recognized by the European Commission, i.e. a method of betaray weakening (accordance with the reference methods specified in Annex VI of the CAFE Directive). On the other hand, the accuracy of indications of the HMP 45A sensor installed permanently on the station was periodically checked by comparing with the indications of an identical device, which is a measuring element of a portable temperature and humidity meter of the same company, calibrated every two years at the Central Office of Measures. All devices worked at stations in a round-the-clock manner on all days of the year with small interruptions (about $1 \%$ of the time), dedicated to servicing and calibration.

\section{Results and discussion}

The choice to analyze PM10 was due to the fact that it is one of the two main atmospheric pollutants (sulfur dioxide and particulate matter) whose levels are the highest during the winter. At the same time, in "favorable" meteorological conditions (mainly inversion of air temperature and weak wind) and high emission of pollutants, particulate matter can cause the so-called "black smog" (Jeż 2009) which means accumulation of pollutants in the atmosphere for a longer period of time (up to a few days). Therefore, PM10 measurements and meteorological data were chosen for analysis, and it was assumed that the variability of PM10 levels would be most apparent in relation to wind direction and speed as well as air temperature and humidity. Based on the above assumptions, the results of PM10 measurements in the Piotrkowice station (Fig. 2) and selected three stations of the Regional Inspectorate for Environmental Protection in Poznan were analyzed: Konin, ul. Wyszyńskiego 3a (referred to as "Konin-Wyszyński”); Poznań, ul. Polanka 24 (referred to as "Poznań-Polanka"); Poznań, ul. Dąbrowskiego 169 (referred to as "Poznań-Botanik").

Atmospheric air monitoring station "Piotrkowice-Konin" is surrounded mainly by arable fields and meadows. From the east and south there are forests occupying $21 \%$ of the whole

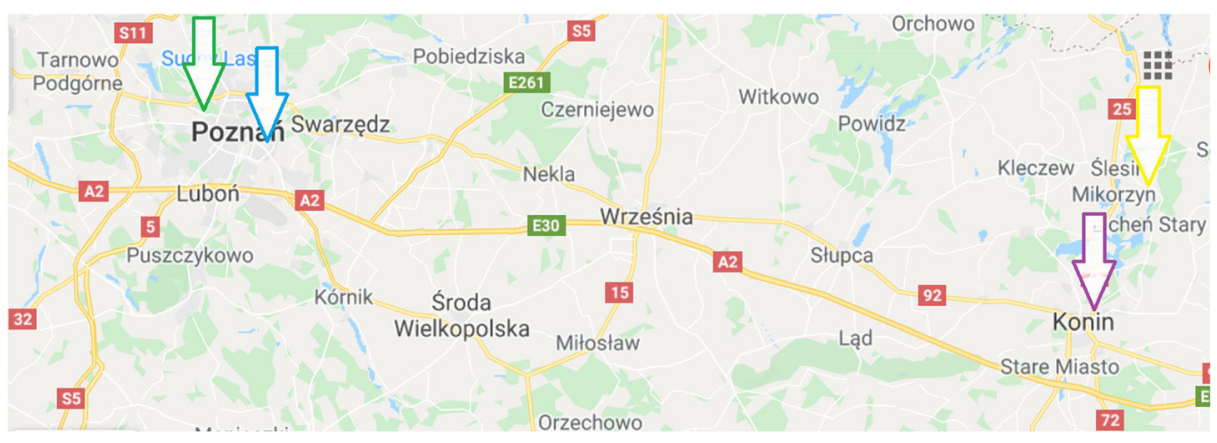

Fig. 2 Location of automatic monitoring stations. (https://www.google.pl/maps/@52.3537164,17.6563638 ,10.05z) 
area of the Ślesin Municipality (Konin Region), where the analyzed measurement station is located. At the same time, the nearest human settlements are located in the following distances: $0.6 \mathrm{~km}$ to the village of Piotrkowice (532 inhabitants), $1.5 \mathrm{~km}$ to the village of Wygoda (270 inhabitants), $2.1 \mathrm{~km}$ to the village of Niedźwiady Duże (163 inhabitants) and $3.1 \mathrm{~km}$ to the village of Półwiosek Stary (263 inhabitants) and approx. $3.5 \mathrm{~km}$ to the city of Ślesin (about 3200 inhabitants) and $4.2 \mathrm{~km}$ to the village of Lichen (about 1500 inhabitants). The stations of the Provincial Environmental Protection Inspectorate in Poznań are located within 2 large settlements (in cities with more than 50,000 inhabitants and a population density above 1500 persons $/ \mathrm{km}^{2}$, applies to both stations in Poznań) and one medium-sized town (5000 to 50,000 inhabitants and population density from 300 to 1500 people $/ \mathrm{km}^{2}$, applies to Konin). The settlement classification was adopted in accordance with the definition of "Organization for Economic Cooperation and Development" and "European Commission - OECD-EC (Dijkstra and Poelman 2012; Servillo et al. 2014).

Results for PM10 from air monitoring stations of the Voivodship Inspectorate for Environmental Protection in Poznan taken into account in the analysis, were used to compare the level of this pollution with the results obtained in the Piotrkowice station and helped us to determine its occurrence at the same time on a larger area.

In Table 1 presents information on the number of days during which smog episodes occurred. Figures 3, 4 and 5 show the distributions of PM10 concentrations depending on wind speed; the results presented relate to the average daily value of PM10 and wind speed. In these drawings, the results of PM10 suspended particulate concentrations from the monitoring station in Piotrkowice were marked as yellow columns with the term "Piotrkowice", while the results from the station of the Regional Inspectorate for Environmental Protection were shown as dots in green, blue and purple, marked in the legend of "Poznań-Botanik", "PoznańPolanka" and "Konin-Wyszyński".

Monitoring stations in Poznan, located in large settlements, recorded significantly more smog days, with exceeded permissible levels of suspended particulate matter in the air than Station Piotrkowice located outside the city, in the area of village. This confirms the thesis that the main source of air pollution are low emissions from individual heating systems which dominate the city. In the area village Piotrkowice it's air quality is much better, even in periods that are particularly conducive to smog formation.

The values of temperature and humidity are shown below in Tables 2 and 3 as 24-h averaged results for each month. Then, the average values for each month over the period considered, i.e. from 2009 to 2015, were calculated. To illustrate calculations, in the case of temperature, the function "conditional formatting" was used to obtain the colors presented in Table 2. At the same time, it was assumed that the height of the "bar" means the absolute value of temperature, while the blue color refers to the negative temperatures and the red ones are

Table 1 Number of smog days from the two-month winter period, i.e. December-January in years 2009-2015

\begin{tabular}{lrrlr}
\hline Year & Station Piotrkowice & Station Konin-Wyszyński & Station Poznań-Polanka & Station Poznań-Botanik \\
\hline $2009-2010$ & 14 & 14 & 31 & 36 \\
$2010-2011$ & 7 & 14 & 23 & 29 \\
$2011-2012$ & 1 & 1 & 12 & 14 \\
$2012-2013$ & 15 & 30 & 31 & 22 \\
$2013-2014$ & 4 & 10 & 16 & 8 \\
$2014-2015$ & 2 & 13 & 12 & 15 \\
\hline
\end{tabular}


Wind speed $[\mathrm{m} / \mathrm{s}]$

오

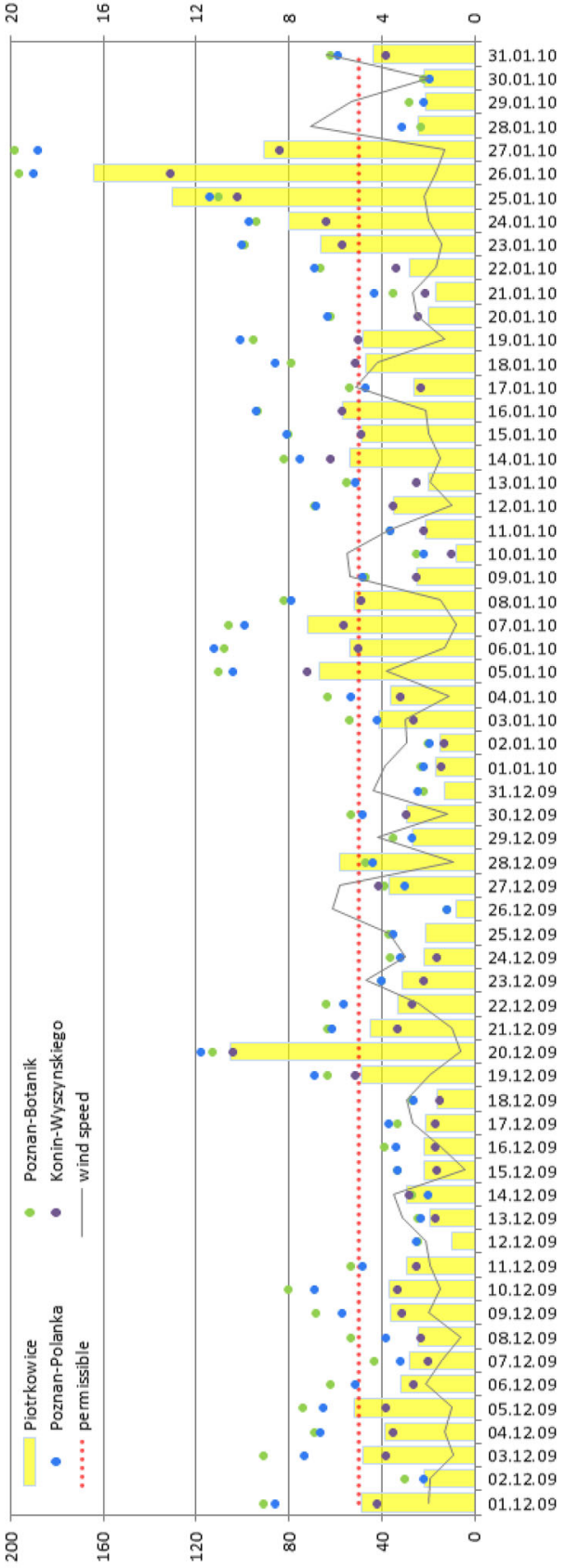

PM10 concentration $\left[\mu \mathrm{g} / \mathrm{m}^{3}\right]$
Wind speed $[\mathrm{m} / \mathrm{s}]$

유

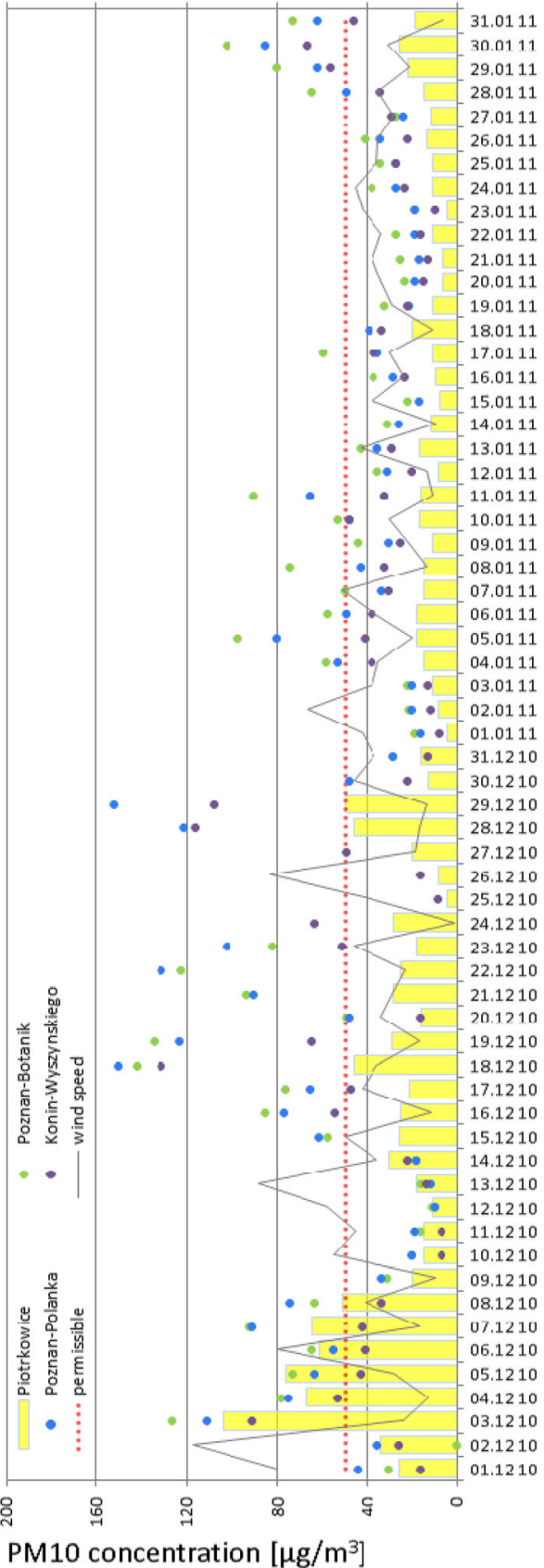

Fig. 3 PM10 particulate matter concentration depending on wind speed in December 2009 and January 2010 and in December 2010 and January 2011 


\section{Wind speed $[\mathrm{m} / \mathrm{s}]$}

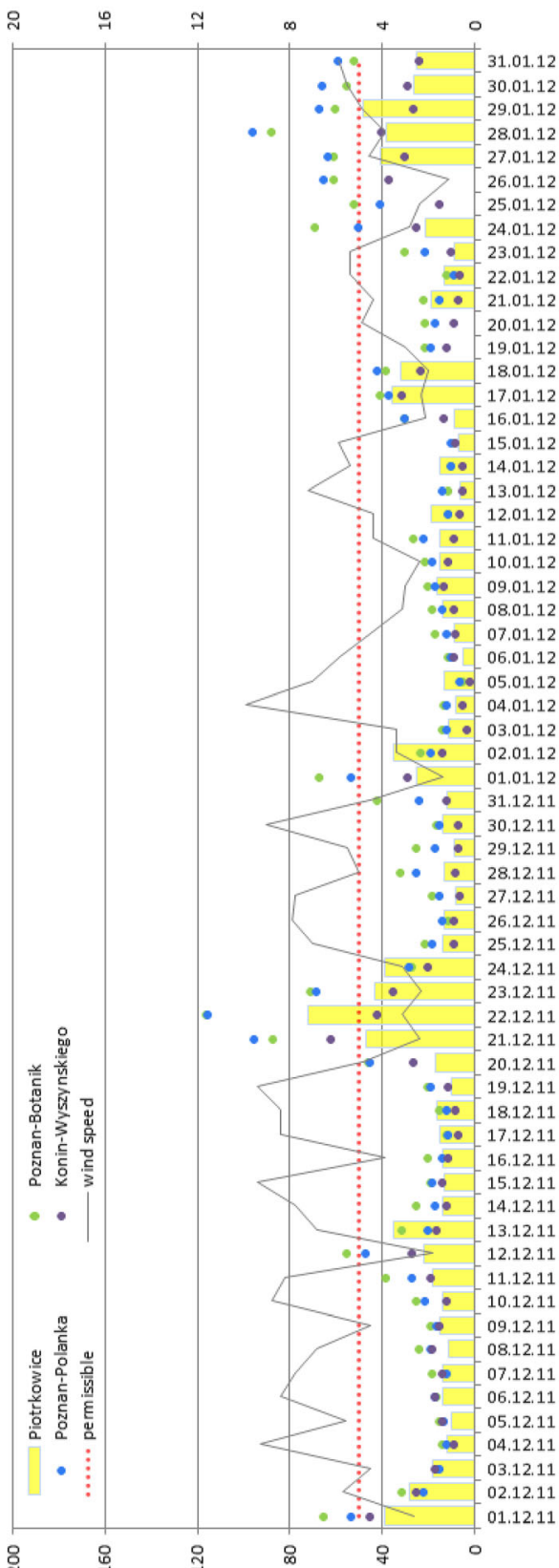

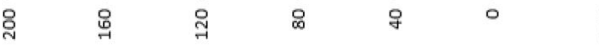

PM10 concentration $\left[\mu \mathrm{g} / \mathrm{m}^{3}\right]$
Wind speed $[\mathrm{m} / \mathrm{s}]$

ล

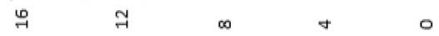

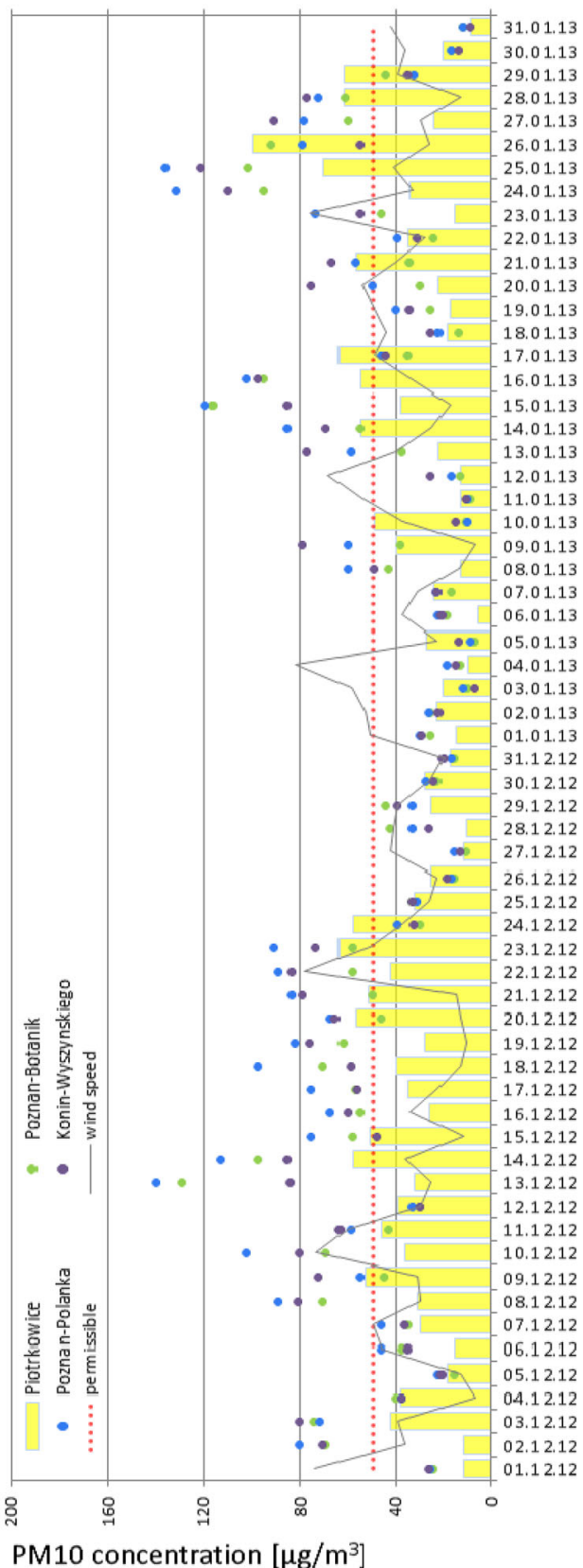

Fig. 4 PM10 particulate matter concentration depending on wind speed in December 2011 and January 2012 and in December 2012 and January 2013 


\section{Wind speed $[\mathrm{m} / \mathrm{s}]$}

\section{요}

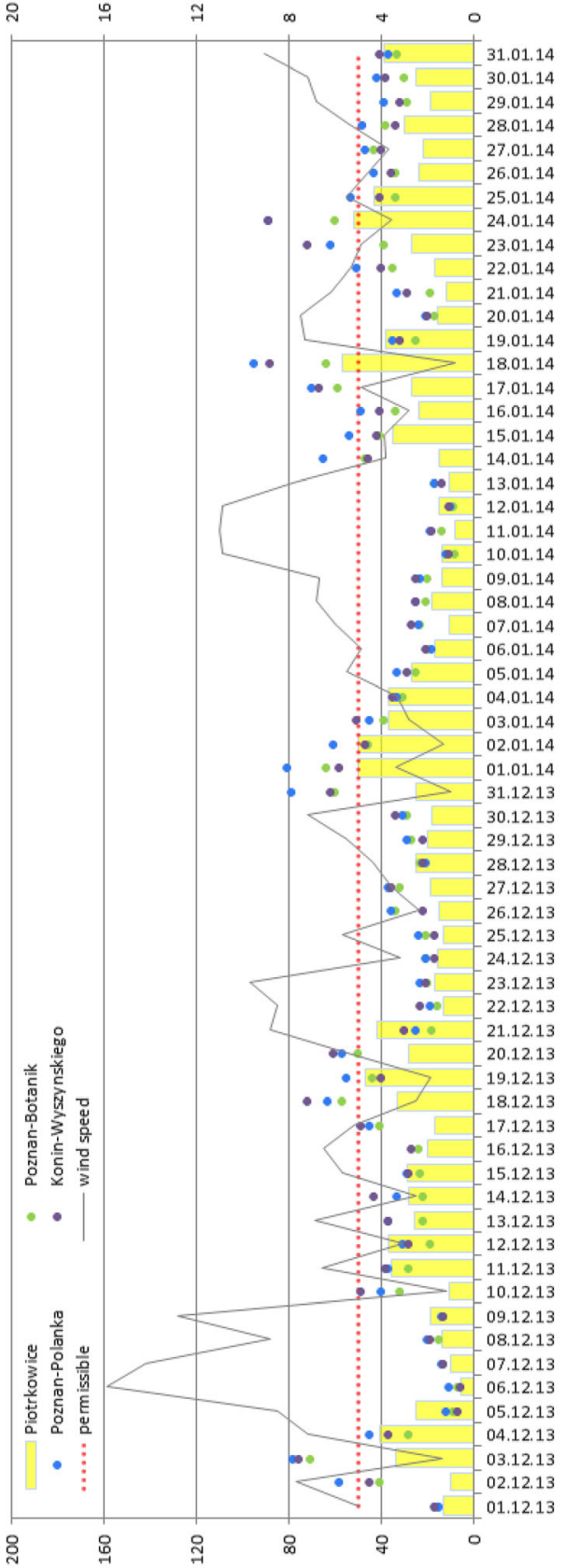

PM10 concentration $\left[\mu \mathrm{g} / \mathrm{m}^{3}\right]$

\section{Wind speed $[\mathrm{m} / \mathrm{s}]$}

요

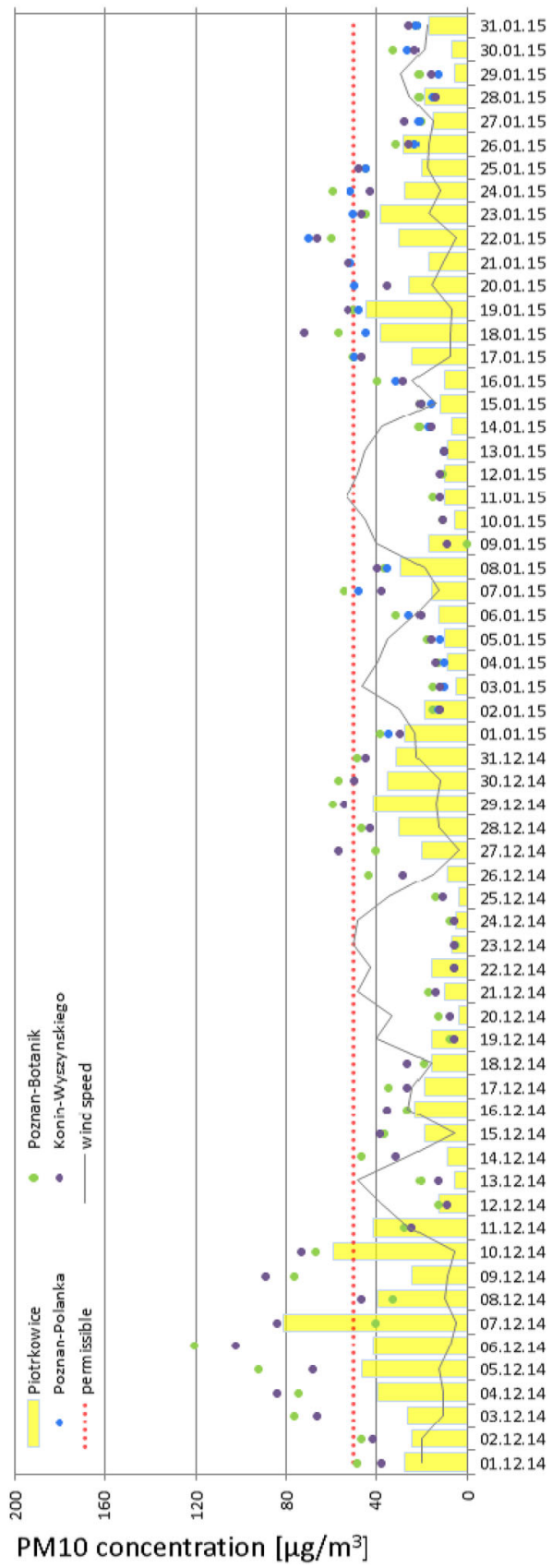

Fig. 5 PM10 particulate matter concentration depending on wind speed in December 2013 and January 2014 and in December 2014 and January 2015 
Table 2 Mean temperature values $\left[{ }^{\circ} \mathrm{C}\right]$ in months and years 2009-2015 (Monitoring Station Piotrkowice)

\begin{tabular}{lrrrrrrrr}
\hline $\begin{array}{l}\text { year } \\
\text { month }\end{array}$ & 2009 & 2010 & 2011 & 2012 & 2013 & 2014 & 2015 & average \\
\hline January & $-2,8$ & $-7,0$ & $-0,1$ & 0,2 & $-3,3$ & $-1,9$ & 1,5 & $-1,9$ \\
February & $-0,2$ & $-1,2$ & $-4,0$ & $-6,4$ & $-0,5$ & 2,9 & 0,9 & $-1,2$ \\
March & 3,4 & 4,1 & 2,8 & 5,4 & $-2,4$ & 6,4 & 5,2 & 3,6 \\
April & 11,6 & 9,3 & 11,3 & 8,4 & 7,6 & 11,0 & 8,4 & 9,7 \\
May & 13,7 & 13,2 & 15,2 & 17,1 & 15,2 & 14,2 & 13,8 & 14,6 \\
June & 15,8 & 17,4 & 19,4 & 16,7 & 19,0 & 17,4 & 17,4 & 17,6 \\
July & 19,7 & 22,6 & 19,1 & 21,3 & 20,4 & 22,8 & 20,8 & 21,0 \\
August & 19,6 & 20,1 & 20,1 & 20,0 & 20,1 & 19,1 & 23,4 & 20,3 \\
September & 15,7 & 13,1 & 16,0 & 15,3 & 13,3 & 16,3 & 16,3 & 15,1 \\
October & 7,5 & 6,4 & 10,1 & 9,2 & 10,6 & 11,1 & 8,0 & 9,0 \\
November & 5,9 & 5,9 & 4,0 & 5,7 & 5,5 & 6,1 & 6,0 & 5,6 \\
December & $-0,6$ & $-6,6$ & 3,3 & $-1,9$ & 2,8 & 1,3 & 5,8 & 0,6 \\
\hline
\end{tabular}

positive. However, the color of cells in Table 3 was determined in such a way that the highest values (i.e. the air with the highest humidity percentage) were dark blue, and the lowest values (the smallest humidity) were marked in red.

As a result, differences between the individual temperatures (Table 2) in subsequent years and the average which they determine, as well as differences between average temperatures in each year were distinguished. In the same way air humidity was analyzed (Table 3) and reduced through averaging to mean monthly values from the subsequent years and from the seven-year period. Due to such analysis of results we can find that there are months or groups of months with periods of similar humidity (dry or humid periods). As a result we can observe differences between mean monthly values from subsequent years and an average from the seven-year period. It is also possible to detect differences in air humidity between the years in the same months, which may indicate the amount of precipitation which in turn can have an influence on the level of air pollution (Cichowicz et al. 2017).

Figures 6 and 7 shows the percentages of particular wind directions and the average wind speed in 2009-2015 based on 1-h data. The determined and marked SW and WSW directions

Table 3 Average humidity values [\%] in particular months and years 2009-2015 (Monitoring Station Piotrkowice)

\begin{tabular}{lllllllll}
\hline $\begin{array}{l}\text { year } \\
\text { month }\end{array}$ & 2009 & 2010 & 2011 & 2012 & 2013 & 2014 & 2015 & average \\
\hline January & 84,9 & 82,5 & 88,6 & 83,9 & 84,8 & 84,2 & 83,5 & 84,6 \\
February & 85,6 & 82,1 & 79,2 & 77,0 & 85,8 & 77,5 & 80,5 & 81,1 \\
March & 81,8 & 75,6 & 71,5 & 72,9 & 72,1 & 75,1 & 71,3 & 74,3 \\
April & 60,5 & 69,5 & 63,7 & 64,2 & 72,8 & 68,1 & 65,3 & 66,3 \\
May & 67,8 & 79,4 & 62,0 & 57,8 & 71,7 & 71,0 & 62,8 & 67,5 \\
June & 79,4 & 70,9 & 62,7 & 70,6 & 71,2 & 67,6 & 63,6 & 69,4 \\
July & 74,3 & 66,3 & 75,2 & 69,7 & 69,9 & 63,6 & 62,2 & 68,8 \\
August & 67,2 & 76,3 & 69,7 & 67,5 & 68,4 & 70,7 & 52,7 & 67,5 \\
September & 73,8 & 81,9 & 70,0 & 73,3 & 79,4 & 73,9 & 70,5 & 74,7 \\
October & 85,1 & 77,5 & 77,1 & 80,6 & 79,6 & 82,6 & 78,1 & 80,1 \\
November & 84,4 & 88,1 & 83,5 & 88,0 & 87,2 & 88,5 & 85,6 & 86,5 \\
December & 86,1 & 87,2 & 83,5 & 87,2 & 84,0 & 84,4 & 83,6 & 85,2 \\
\hline
\end{tabular}




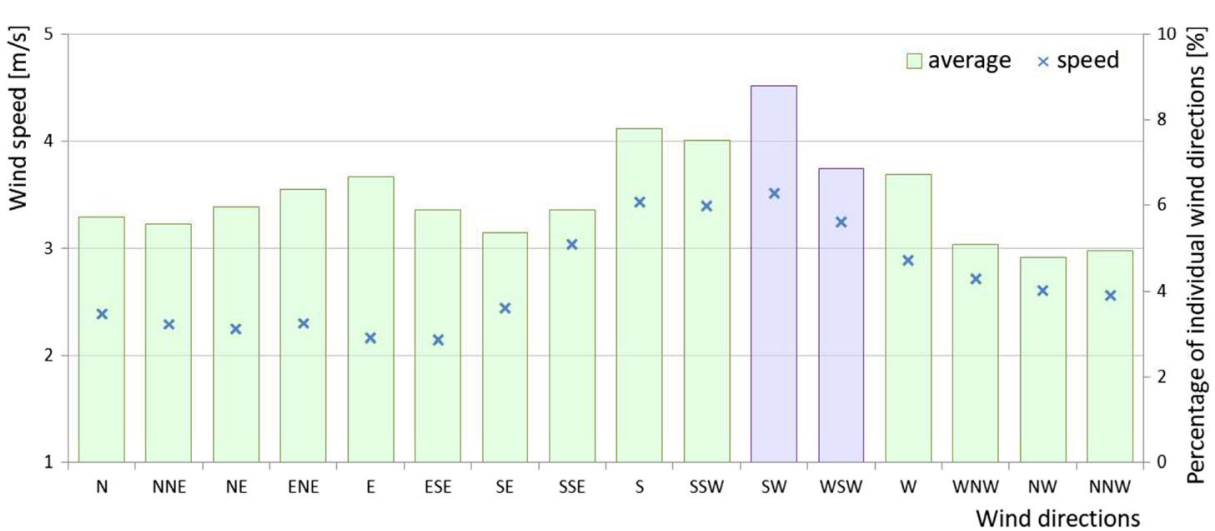

Fig. 6 Percentage of individual wind directions and average wind speed in 2009-2015 (Monitoring Station Piotrkowice)
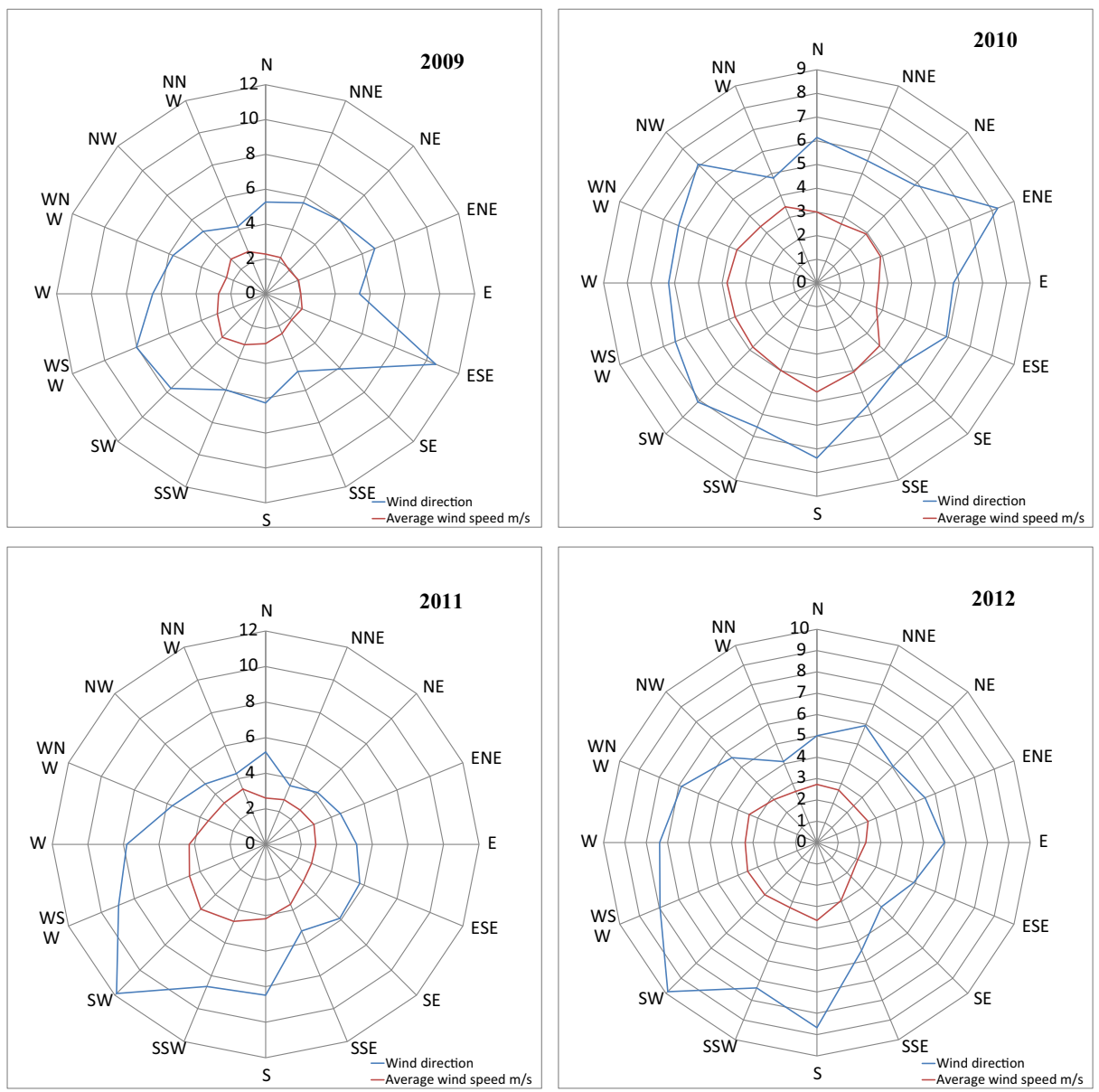

Fig. 7 Wind rose for analyzed area (Monitoring Station Piotrkowice) 

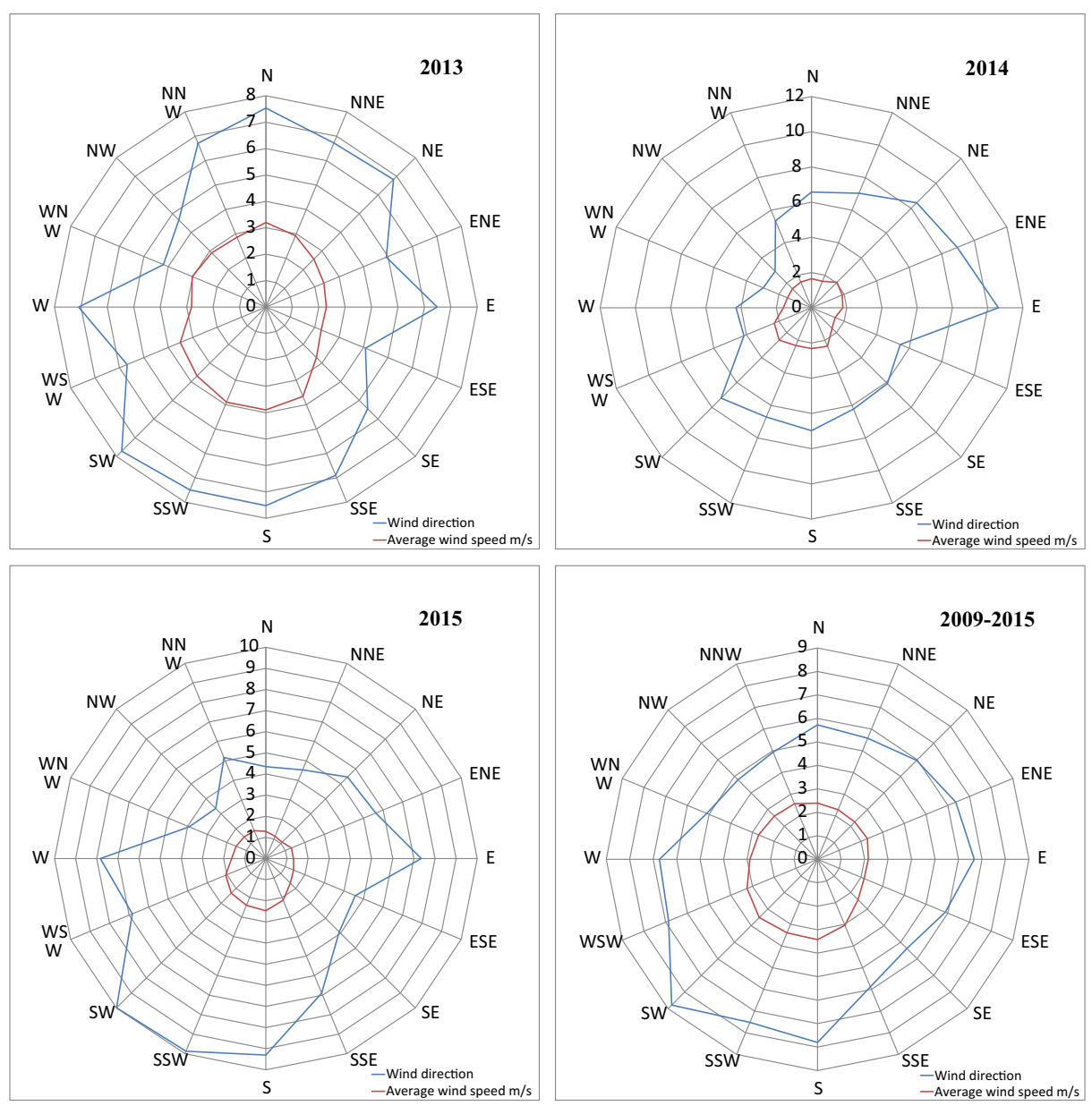

Fig. 7 (continued)

(violet color) result from the location of large industrial plants in these directions. The results of the percentage share of the wind direction were marked with vertical columns in green color and were defined in the legend as "direction" and also information about average wind speeds were given, denoting them with crosses in blue with the term "speed" .

The meteorological data presented in Tables 2 and 3 and in Figs. 6 and 7 relate to the Piotrkowice monitoring station.

In contrast, Fig. 8 presents the results of calculations of distributions for PM10 suspended particulate matter in individual months depending on meteorological conditions, including wind speed. At the same time, the calculation has been referred to the acceptable level, which is $50 \mu \mathrm{g} / \mathrm{m}^{3}$ and concerns the $24-\mathrm{h}$ value. The calculations of the mean, maximum 24-h values from particular months of the seven-year period were made, and the average for each month was determined from them. In addition, the cases of exceedance of daily average values were also analyzed, as their permissible number during the year is 35 . Very often it is a problem for particular cities/ towns/villages. 


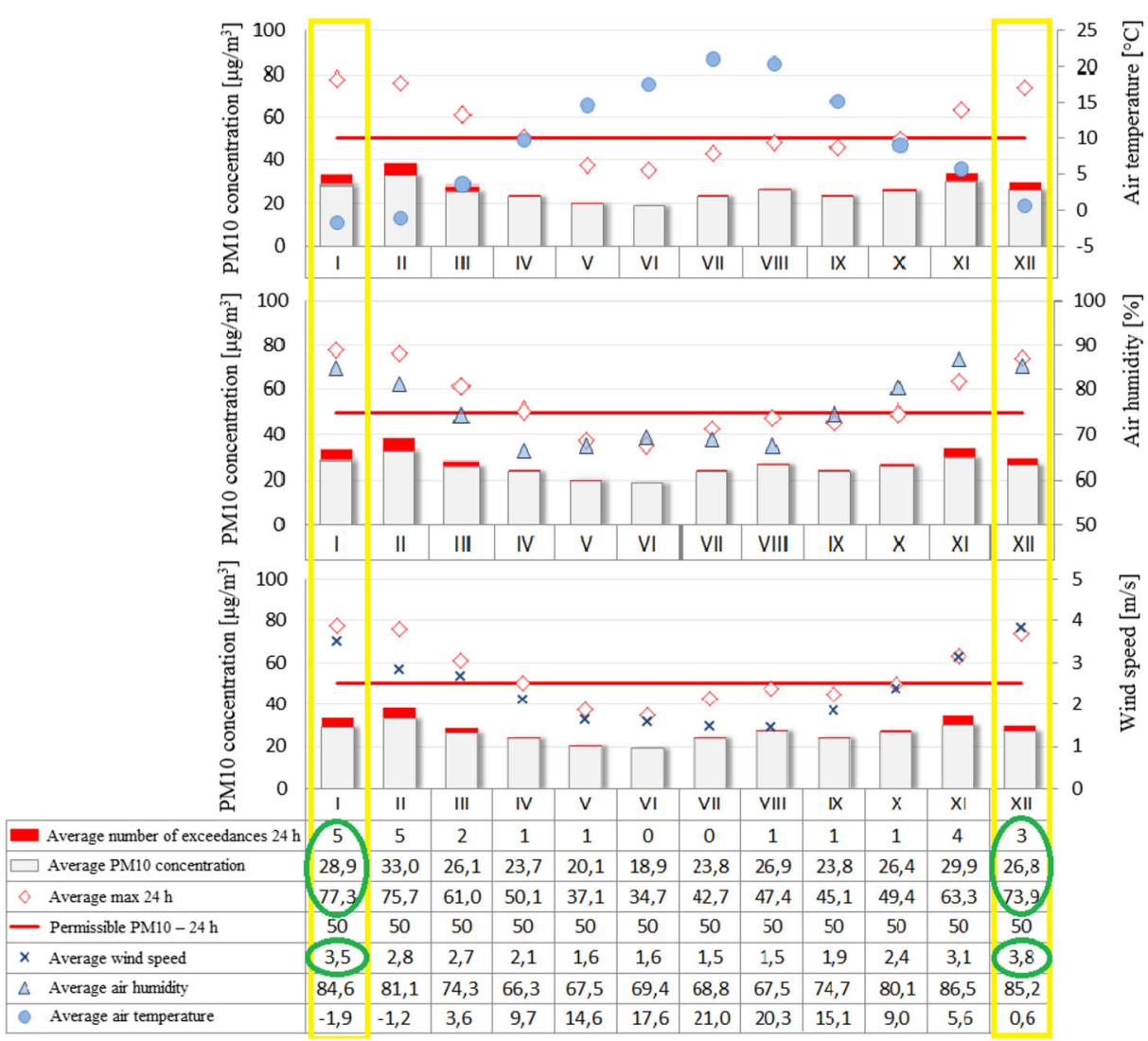

Fig. 8 Concentration of PM10 of Monitoring Station Piotrkowice as a function of air temperature, humidity and wind speed in particular months of the year (Cichowicz et al. 2017) - data from the two-month winter period are marked in yellow and green color

The analysis confirmed (Fig. 8) that with low speeds of wind higher values of particulate matter PM10 were observed (data from the two-month winter period marked in yellow and green). However, when analyzing the data the twelve-month, it can be noticed that the general rule that at low wind speeds the most high concentrations of PM10 are observed not met. This is due to the proximity of the station from a large power plant, which in the summer (when there are mostly low wind speeds) works with less power emitting less pollution.

\section{Conclusions}

The effect of wind speed on air quality has been well-known and obvious (Boubel et al. 1994). It is well-known, that low wind speed promotes the formation of smog phenomena in cities. In the literature one can find many publications describing this phenomenon in relation to urban areas (Godish et al. 2015). This study, was decided to check whether such dependencies are also found in rural areas and whether the emission of pollutants from a large power plant affects the air pollution condition 
registered at the measurement station and whether the observed concentrations are also changed in accordance with changes of meteorological conditions.

When analyzing the results, many situations are observed when higher PM10 values appear at low wind speeds and vice versa, i.e. at higher wind speeds, the value of PM10 is decreasing. This is due to larger "ventilation" of the air masses in the area considered and the displacement of pollutants over longer distances. On the other hand, elevated values of particulate matter PM10 are a consequence of higher pollutant emissions during these periods (Figs. 4 and 5). The analysis also confirms the fluctuation (Figs. 3, 4 and 5) of PM10 levels registered both by the station in Piotrkowice and obtained from the WIOŚ Poznań. When comparing the concentrations of suspended particulate matter PM10 from both data sources, it can be observed that levels of this pollution recorded by the WIOŚ station in the periods of low wind speed were higher than the levels recorded in the Piotrkowice monitoring station. This may be related to the location of that station in the larger agglomeration and, therefore, higher emissions from car transport.

In conclusion, based on the data analyzed from the selected air quality monitoring station, it can be noted that in the analyzed period, the average PM10 concentration level for the two-month winter period (i.e. December-January from 2009 to 2015) was $27.8 \mu \mathrm{g} / \mathrm{m}^{3}$ and was higher than the average level for $12 \mathrm{months}-25.7 \mu \mathrm{g} / \mathrm{m}^{3}$. These year-on-year concentrations changed irregularly, which does not allow unambiguous delineation of the trend line. As a consequence, it was noted that in the year-on-year analysis for the two-month period in 2010 and 2013 there were increases in PM10 concentrations by $0.6 \%$ and $4.0 \%$ respectively, while in 2012 there was an increase by as much as $61.9 \%$ which resulted from the drop in the average concentration in 2011 by $57.6 \%$, respectively. The drop in concentrations also occurred in 2015 by $29.1 \%$. At the same time, a more regular trend for the average PM10 concentration level for 12 months is noticeable, because in 2010, 2011, 2013 and 2015 they were respectively smaller year-on-year by $13.2 \%, 5.10 \%, 1.0 \%$ and $0.2 \%$, while they increased in 2012 and 2014 by $4.6 \%$ and $1.6 \%$, respectively.

Irregular changes registered in the winter period are most probably related to the winter temperature inversion, which is more and more often appearing in winter in Poland, lasting several times over a dozen or so days, which intensifies smog phenomena. The occurrence of dust smog in the vicinity of the monitoring station is the result of emission from emittors of small domestic furnaces, obsolete, fired with poor quality coal, where many of which are exploited in rural areas and small towns. The probable source of smog in this area is also intensive car transport.

\footnotetext{
Open Access This article is licensed under a Creative Commons Attribution 4.0 International License, which permits use, sharing, adaptation, distribution and reproduction in any medium or format, as long as you give appropriate credit to the original author(s) and the source, provide a link to the Creative Commons licence, and indicate if changes were made. The images or other third party material in this article are included in the article's Creative Commons licence, unless indicated otherwise in a credit line to the material. If material is not included in the article's Creative Commons licence and your intended use is not permitted by statutory regulation or exceeds the permitted use, you will need to obtain permission directly from the copyright holder. To view a copy of this licence, visit http://creativecommons.org/licenses/by/4.0/.
} 


\section{References}

Boubel RW, Fox DL, Rurner DB, Stern AC (1994) Fundamental of Air Pollution. Academic Press, San Diego

Brook, R.D., Bard, R.L., Morishita, M., Dvonch, J.T., Wang, L., Yang, H., Spino, C., Mukherjee, B., Kaplan, M.J., Yalavarthi, S., Oral, E.A., Ajluni, N., Sun, Q., Brook, J.R., Harkema, J., Rajagopalan, S.: Hemodynamic, autonomic, and vascular effects of exposure to coarse particulate matter air pollution from a rural location. Environ. Health Perspect. 122(6), 624-630 (2014). https://doi.org/10.1289/ehp.1306595

Cichowicz, R., Wielgosiński, G.: Effect of meteorological conditions and building location on $\mathrm{CO}_{2}$ concentration in the university campus. Ecological Chemistry and Engineering S. 22(4), 513-525 (2015a). https://doi. org/10.1515/eces-2015-0030

Cichowicz, R., Wielgosiński, G.: Effect of urban traffic on the immision of carbon dioxide in the university campus. Ecological Chemistry and Engineering S. 22(2), 189-200 (2015b). https://doi.org/10.1515/eces2015-0010

Cichowicz, R., Wielgosiński, G., Fetter, W.: Dispersion of atmospheric air pollution in summer and winter season. Environ. Monit. Assess. 189, 605 (2017). https://doi.org/10.1007/s10661-017-6319-2

Deligiorgi, D., Philippopoulos, K., Karvounis, G.: Estimation of pollution dispersion patterns of a power plant plume in complex terrain. Global NEST Journal. 15(2), 227-240 (2013) https://journal.gnest. org/sites/default/files/Journal\%20Papers/227-240 955 Deligiorgi 15-2.pdf

Dijkstra, L., Poelman, H., 2012. Cities in Europe. The new OECD-EU definition. Brussels. European Comission Regional Focus Report. RF 01/2012

EEA Report No 28 (2016) Air quality in Europe - 2016 report, Publications Office of the European Union, doi: https://doi.org/10.2800/80982

Godish T, Davis WT, Fu JS (2015) Air Quality. CRC Press, London

Huang, W., Zhu, T., Pan, X., Hu, M., Lu, S.-E., Lin, Y., Wang, T., Zhang, Y., Tang, X.: Air pollution and autonomic and vascular dysfunction in patients with cardiovascular disease: interactions of systemic inflammation, overweight, and gender. Am. J. Epidemiol. 176(2), 117-126 (2012). https://doi.org/10.1093 /aje/kwr511

Jeż M (2009) Ochrona Atmosfery. Oficyna Wydawnicza Wyższej Szkoły Ekologii i Zarządzania, Warszawa

Kampa M, Castanas E (2008) Human health effects of air pollution. Environmental pollution 151(2): 362-367, https://doi.org/10.1016/j.envpol.2007.06.012

Makhiniashvili I, Makles Z (2006) Smog w środowisku miejskim. Bezpieczeństwo Pracy 7-8: 20-23, http://archiwum.ciop.pl/20785

Moreira D, Vilhena M (2009) Air Pollution and Turbulence: Modeling and Applications. CRC Press

QGIS n.d. version 2.18.19 (Free and Open Source Software)

Samet JM, Rappold A, Graff D, Cascio WE, Berntsen JH, Huang Y-ChT, Herbst M, Bassett M, Montilla T, Hazucha MJ, Bromberg PA, Devlin RB (2009) Concentrated ambient ultrafine particle exposure induces cardiac changes in young healthy volunteers. American journal of respiratory and critical care medicine 179(11), https://doi.org/10.1164/rccm.200807-1043OC

Seaton A, Godden D, MacNee W, Donaldson K (1995) Particulate air pollution and acute health effects. The lancet 345(8943):176-178, https://doi.org/10.1016/S0140-6736(95)90173-6

Servillo, L., Atkinson, R., Smith, I., Russo, A., Sýkora, L., Demazière, C., Hamdouch, A. 2014. TOWN, Small and Medium Sized Towns in their Functional Territorial Context, Final Report, Espon, Luxembourg

Turner DB (1994) Workbook of Atmospheric Dispersion Estimates: an Introduction to Dispersion Modeling. CRC Press

Zarzycki R, Imbierowicz M, Stelmachowski M (2007) Wprowadzenie do inżynierii i ochrony środowiska. Ochrona środowiska naturalnego. Część 1, WNT, Warszawa

Publisher's note Springer Nature remains neutral with regard to jurisdictional claims in published maps and institutional affiliations. 